Caligrama, Belo Horizonte, v. 22, n. 1, p. 29-49, 2017

\title{
Sob o signo da deusa Deméter: as mulheres no romance Lazarilho de Tormes e no conto "Mon Gigolô", de Marcos Rey
}

\author{
Under the sign of Demeter: the women in the novel \\ Lazarilho de Tormes and in the short-story "Mon Gigolô", \\ by Marcos Rey
}

\begin{abstract}
Altamir Botoso
Universidade Estadual de Mato Grosso do Sul, Campo Grande, Mato Grosso do Sul / Brasil

abotoso@uol.com.br
\end{abstract}

Resumo: Este artigo objetiva estudar comparativamente as mulheres do romance Lazarilho de Tormes e as do conto "Mon Gigolô", de Marcos Rey. Observa-se, nessas duas narrativas, que as representações femininas apresentam um comportamento regido pela deusa grega Deméter, que se caracteriza por defender, alimentar e proteger os homens. Portanto, as personagens femininas dos textos ficcionais mencionados assumem um comportamento maternal em relação aos homens com os quais entram em contato em seus respectivos contextos ficcionais.

Palavras-chave: mulheres; Deméter; Marcos Rey; romance picaresco; literatura comparada.

Abstract: It is intended, in this article, to study comparatively the women from the novel Lazarilho de Tormes and from the short-story "Mon Gigolô", by Marcos Rey. It is noticed in these two narratives, that the female representations presents a behaviour guided by the greek goddess Demeter, which is characterized by the fact of defending, feeding and protecting men. Therefore, the female characters from these fictional texts mentioned adopt a maternal behavior related to the men with whom they make contact in their respective fictional contexts.

Keywords: women; Demeter; Marcos Rey; picaresque novel; comparative literature. 
Recebido em: 9 de setembro de 2016.

Aprovado em: 31 de maio de 2017.

O romance picaresco é uma modalidade literária que abrange um conjunto de obras escritas na Espanha, nos séculos XVI e XVII. Seu eixo centra-se no pícaro, personagem de baixa condição social, que procura por todos os meios possíveis - a trapaça, o engano, o roubo, o rufianismo - ascender socialmente. Três obras constituem o núcleo clássico, ou picaresca clássica: Lazarillo de Tormes, de autor desconhecido, publicada em 1554; Guzmán de Alfarache, de Mateo Alemán (1547-1615?), cuja primeira parte apareceu em 1599 e a segunda, em 1604; e El Buscón, de Francisco de Quevedo (1580-1645), que vem a público no ano de 1626. Com base no que é comum a estas obras, Mário Miguel González (2010, p. 314) afirma que o romance picaresco é "a pseudoautobiografia de um anti-herói, definido como um marginal à sociedade, o qual narra suas aventuras que, por sua vez, são a síntese crítica de um processo de ascensão social pela trapaça e representam uma sátira da sociedade contemporânea do pícaro, seu protagonista".

Todas as três obras apontadas são a história de um anti-herói que, valendo-se da astúcia, procura integrar-se à sociedade, narrando ele próprio as suas aventuras e desventuras, de forma autobiográfica.

Assim, o Lazarilho inicia o gênero, contrapondo-se parodicamente aos romances de cavalaria:

[...] O autor do Lazarillo de Tormes, na narração autobiográfica de Lázaro, se apodera de traços de modelos de narrativas documentais e acrescenta a estes um sentido de paródia dos textos ficcionais mais difundidos na primeira metade do século XVI na Espanha: os livros de cavalaria. [...] o eixo do relacionamento possível com os livros de cavalaria está na eliminação do narrador onisciente daqueles e na substituição pelo narrador protagonista; na criação do leitor moderno; no protagonista que deixa de ser o herói modelar da ficção de cavalaria para dar lugar ao anti-herói que parodia aquele, ponto por ponto; no "grosero estilo", diverso do daquele tipo de narrativas, propositadamente adotado; e na presença de coordenadas históricas e geográficas imediatas e concretas, das quais sempre carecem os livros de cavalaria. 
A eliminação do narrador onisciente no Lazarillo de Tormes nos coloca, como diz Américo Castro, no interior da experiência do próprio protagonista. Dessa maneira, já não estaremos perante a reiteração de um estereótipo narrativo que não pode sofrer maiores variações, como era o caso do herói dos livros de cavalaria. $\mathrm{O}$ texto não mais será a expressão do que acontece a alguém, mas do homem existindo no que acontece. E a série de acontecimentos não ficará aberta - como nos livros mencionados -, mas se fecha na conclusão de um processo explicado no universo existencial do protagonista. [...] (GONZÁLEZ, 2010, p. 311-312).

O romance picaresco espanhol teve o grande mérito de colocar em primeiro plano a figura de um anti-herói que narra os feitos de sua vida nada grandiosa, quando o comparamos com o protagonista dos romances da época, a figura do cavaleiro andante, uma espécie de super-herói, cujas ações altruístas procuravam beneficiar os mais fracos, na tentativa de livrá-los de qualquer tipo de opressão.

O pícaro funciona como a antítese do cavaleiro andante, pois pensa somente em si mesmo, em tirar vantagens em todas as situações que a vida lhe oferece, em suma, ele é movido pela praticidade, não se deixa dominar pela paixão ou qualquer sentimento amoroso, como ocorria com as personagens centrais dos romances de cavalaria.

$\mathrm{Na}$ narrativa que inicia o gênero, o leitor depara-se com a história de Lázaro de Tormes, um individualista, que busca obstinadamente a ascensão ao âmago da sociedade que ele critica em seu relato. Será criado de vários amos: um cego astuto, que quase o faz perecer de fome e a quem tem de enganar para sobreviver, terminando por abandonálo; um clérigo avaro, que o despede depois de descobrir que Lázaro roubava pães de uma arca velha que tinha em sua casa; um escudeiro faminto, único amo pelo qual sentirá certa simpatia e compaixão e que foge, abandonando-o, por não ter como pagar o aluguel da casa onde moram; um frade das Mercês, que o fazia caminhar muito, rompendo seu primeiro par de sapatos.

Os próximos amos de Lázaro serão um vendedor de indulgências, com o qual permanece por quatro meses nos quais presencia uma série de embustes perpetrados por este para conseguir vender suas absolvições; um mestre de pintar pandeiros, do qual também sofreu maus-tratos; um capelão trabalhando como "vendedor de água, com um asno, quatro 
cântaros e um chicote e do qual Lázaro tira bom proveito" (BARBOSA; RODRIGUES, 2000, p. 55) - dividindo o que ganha com esse amo, consegue comprar uma roupa usada e o abandona -; um aguazil, tipo de oficial da polícia espanhola, que Lázaro deixa pelos perigos que ambos tiveram que enfrentar; e um arcipreste - nesse momento Lázaro se torna pregoeiro de vinhos da cidade de Toledo.

Em relação a este último amo, verificamos que com ele Lázaro consegue integrar-se à sociedade, ainda que de forma baixa e vil, uma vez que o arcipreste faz com que Lázaro aceite casar-se com sua amante, fechando os olhos e os ouvidos à traição da esposa, apesar dos comentários de todos. Desta forma, viverá no que ele considera como sua "prosperidade e no auge de toda boa fortuna" (LAZARILHO..., 1992, p. 105).

A figura do pícaro não ficou restrita à literatura espanhola, uma vez que seres ficcionais com características semelhantes às suas surgiram em outros países, e todos esses "literariamente, garantem e consagram, em seus respectivos contextos, o espaço do anti-herói” (MILTON, 1986, p. 75). A esse respeito, é possível afirmar que

O romance picaresco projetar-se-ia, posteriormente, no restante da Europa, onde - principalmente na Alemanha, Inglaterra e França - registram-se romances inspirados no modelo espanhol, publicados durante os séculos XVII e XVIII. Nos séculos XIX e XX, é possível verificar, em diversas literaturas, especialmente ibero-americanas, $\mathrm{o}$ aparecimento de narrativas que, propositadamente ou não, respondem ao que poderia ser um conceito de romance picaresco. (GONZÁLEZ, 2010, p. 314).

Em solo brasileiro, o malandro, que se configura como personagem principal em vários romances da década de 80 , do século XX, conforme pontua Mario González (1994, p. 315), pode ser visto como uma recriação do pícaro espanhol, pois é uma personagem que age fora das normas estabelecidas pela sociedade, usa a astúcia para se safar de situações conflituosas e para obter vantagens para si, recusa o trabalho rotineiro e quer ascender socialmente, de preferência com o mínimo esforço.

Há uma série de estudos que comparam o pícaro espanhol e o malandro brasileiro, considerando-os seres ficcionalmente correlatos. Destacam-se, no tocante a esse aspecto, as pesquisas desenvolvidas por Mario Miguel González (1994), que culminaram no livro A saga do antiheró, além das seguintes pesquisas: A picaresca espanhola e Macunaíma de Mário de Andrade, de Heloisa Costa Milton (1986); Formação 
malandra: Bildungsroman e picaresca em Memórias sentimentais de João Miramar, e Amar, verbo intransitivo, de Daniel Argolo Estill (1996); Madame Pommery: a primeira malandra na prosa ficcional brasileira, de José Carlos Mariano do Carmo (2003); Meu tio Atahualpa de Paulo de Carvalho Neto: o enigma mulher no universo feminino do romance malandro, de Maria Josele Bucco Coelho (2006), entre outras.

As considerações acima se fazem necessárias, já que o conto "Mon Gigolô", de Marcos Rey (1925-1999), que será analisado neste artigo, apresenta como protagonista um malandro, que, recusando-se a entrar para o mundo massificado do trabalho, transforma-se num gigolô, que vive da exploração das mulheres que cruzam o seu caminho, até se apaixonar por Celina, que se casa com um de seus clientes, Romeu. Conforma-se, assim, um triângulo amoroso, pois Mon Gigolô apresenta-se como primo de Celina, e esta garante que o visitará sempre, preservando o papel de amante deste e o de esposa daquele.

Tendo em vista o grande número de estudos comparativos das personagens picarescas e as malandras, os quais evidenciam o protagonismo de pícaros e malandros nos romances nos quais atuam, o nosso objetivo é empreender uma análise comparativa das mulheres que circundam Lázaro de Tormes e Mon Gigolô, em suas respectivas narrativas. Tais figuras femininas míticas, entre muitas outras mais óbvias, como a da deusa Atena, que acompanha Ulisses na composição de ardis em sua trajetória odisseica, podem ser lidas, em ambas as histórias, como seres que auxiliam o pícaro e o malandro, garantindo-lhes o sustento. Nesse sentido, propomo-nos aproximar a deusa grega Deméter (ou Ceres, para os romanos) das personagens femininas para provocar com isso a releitura dos textos referidos.

Na mitologia grega, a deusa mencionada é filha de Cronos e Reia. Para os romanos, ela é filha de Saturno e Cibele, mas recebe o epíteto de "Grande Mãe" em ambas. A deusa é símbolo da fartura e da bonança, ela socorre os mortais com boas colheitas e, portanto, com alimento para que possam sobreviver:

Ceres $[\ldots]$ ensinou aos homens a arte de cultivar a terra, de semear, de fazer a colheita do trigo, e com ele fabricar o pão, o que a fez ser vista como a deusa da agricultura. [...] Ceres é habitualmente representada sob o aspecto de uma bela mulher, de talhe majestoso, e tez rosada; os seus olhos são lânguidos, os cabelos louros, caindo desordenadamente sobre os ombros. 
Além de uma coroa de espigas de trigo usa um diadema mais alto. Às vezes é coroada por uma grinalda de espigas ou de papoulas, símbolo da fecundidade. O seu peito é forte, os seios opulentos; segura com a mão direita um feixe de espigas, e com a esquerda uma tocha ardente. $O$ vestido cai-lhe até os pés, e muitas vezes leva um véu atirado para trás. Às vezes representam-na com um cetro ou uma foice; duas criancinhas junto do seu seio, cada uma segurando uma cornucópia [vaso em forma chifre], indicam que ela é a nutriz do gênero humano. Traz um vestido amarelo, cor dos trigos maduros. (COMMELIN, s/d, p. 50-53).

Além disso, ela é representada também com atitudes triunfantes, própria da deusa das searas e é

símbolo da terra que oculta aos olhos a sua força fecunda e só deixa ver o que produz. Com a mão direita prende o véu sobre o ombro esquerdo; com a outra aperta contra si um ramalhete dos campos; a coroa de espigas está colocada sobre a cabeleira artisticamente disposta, e levanta ao céu um olhar satisfeito com expressão de reconhecimento pelos outros deuses que a secundaram.

O seu carro é atrelado a leões ou serpentes. Nos monumentos é geralmente chamada de Magna Mater, Mater Maxima (Grande Mãe, Maior das Mães) [...] (COMMELIN, s/d, p. 53).

Portanto, nota-se que Ceres (ou Deméter) apresenta como características arquetípicas femininas a vocação para a maternidade e a capacidade de prover sustento para os mortais, sendo essas as mesmas que marcam as personagens femininas de Lazarilho de Tormes e "Mon Gigolô".

Complementando nossas observações sobre a deusa Ceres/ Deméter, valemo-nos das colocações de Jean Shinoda Bolen (1990), que se encontram em seu livro As deusas e a mulher: nova psicologia das mulheres, no qual a referida autora estuda as forças que influenciam as mulheres por meio das deusas gregas Héstia, Deméter, Hera, Ártemis, Atenas, Afrodite e Perséfone, enquadrando essas deusas em três categorias: "as deusas virgens (Ártemis, Atenas e Héstia), as deusas vulneráveis (Hera, Deméter e Perséfone) e a deusa alquímica (Afrodite)" (RAPUCCI, 2011, p. 71). 
As deusas vulneráveis, conforme elucida Cleide Antonia Rapucci (2011, p. 82-83), personificam arquétipos que representam os papéis tradicionais das mulheres - esposa, mãe e filha - as quais orientam para o relacionamento e expressam a necessidade de afiliação das mulheres. Quando elas são arquétipos dominantes, o enfoque da atenção é nos outros, não num objetivo exterior ou estado interior.

Em síntese, é possível afirmar que a mulher que se associa à figura de Ceres/Deméter apresenta as seguintes características:

A mulher-Deméter é regida pela deusa das colheitas; é uma verdadeira mãe-terra que gosta de estar grávida, de amamentar e de cuidar de crianças; está envolvida com todos os aspectos do nascimento e com os ciclos reprodutivos da mulher.

$[\ldots]$

Deméter é a deusa da maternidade e de tudo que se refere às funções reprodutoras. Por reger a semente e o fruto, é às vezes chamada Senhora das Plantas, simbolizando sua profunda ligação com todos os aspectos da alimentação, do crescimento, dos ciclos das safras, da colheita e preservação dos alimentos. (RAPUCCI, 2011, p. 74-76, grifos da autora).

A configuração da "mulher-Deméter" projeta-se no romance picaresco e no conto em análise, uma vez que a maioria das mulheres recriadas por estes relatos ficcionais deixam patente o seu instinto materno ao se depararem com alguma dificuldade ou carência pela qual atravessam o pícaro ou o malandro, sempre socorrendo e auxiliando esses seres deserdados pela sorte.

A primeira figura feminina a surgir na obra Lazarilho de Tormes é sua mãe, Antona Pérez que, com a morte do marido, Tomé González, o qual fora desterrado por roubar, vai viver na cidade:

Minha viúva mãe, como se visse sem marido e sem proteção, decidiu aproximar-se dos bons para ser um deles. Foi viver na cidade, onde alugou uma casinha, dedicandose a cozinhar para certos estudantes, e lavava a roupa para os tratadores dos cavalos do comendador da Madalena, de modo que foi frequentando as cavalariças.

Ela e um homem moreno, um dos que tratavam dos animais, conheceram-se. Ele, às vezes, vinha a nossa casa e 
ia embora de manhã. Outras vezes, durante o dia, chegavase à porta, com a desculpa de comprar ovos, e entrava em casa [...] (LAZARILHO..., 1992, p. 33).

Vale notar que a mãe de Lázaro, para poder sustentá-lo, apoia-se numa figura masculina, primeiramente, Tomé González e, em seguida, Zaide, o qual também será preso por roubar. Trata-se de uma personagem que vive um processo de degradação, já que se liga somente a parceiros ladrões, tornando-se cúmplice dos dois, "restando ao personagem feminino a submissão e adequação aos moldes rígidos da sociedade" (COELHO, 2009, p. 1594) da época. Assim, a mulher nos romances picarescos aparece sempre degradada, sendo associada "à prostituição e aos engodos que são considerados próprios do gênero" (COELHO, 2009, p. 1594), mas apesar dessa caracterização, ela perpetua a sua imagem como provedora, como aquela que é responsável por sustentar o pícaro, até que ele possa tornar-se independente e ser capaz de cuidar de si próprio.

Em "Mon Gigolô", o protagonista, com a morte da tia, que o sustentava, é obrigado a buscar alternativas para sobreviver, fracassando em todos os seus intentos de ganhar dinheiro com pouco esforço. Todas as suas atividades relacionam-se com o sexo e o erotismo: aluguel de livros pornográficos, venda de retratos e figuras obscenas, a tentativa frustrada de gravar um long-play com os ruídos de duas pessoas fazendo sexo, sessões de cinema erótico nos fundos do barracão da casa de um amigo, a publicação de uma revista com imagens pornográficas, a abertura de uma boutique para venda de bibelôs obscenos, cartões postais indecorosos e livros proibidos. Enfim, todas essas tentativas terminam com a prisão de Mon Gigolô. Em liberdade, ele busca uma nova forma de ganhar algum dinheiro: "Não se deu por vencido: foi cantar velhos tangos num cabaré e deu início à sua carreira de gigolô, com um êxito que despertou inveja e ciumeira de seu meio" (REY, 1990, p. 58).

As mulheres que Mon Gigolô explora podem ser aproximadas da deusa Deméter, uma vez que são elas que garantem o seu sustento:

As amantes de Mon Gigolô eram as mais variadas na forma e no conteúdo: dançarinas de cabarés e taxi-girls, cabeleireiras, uma senhora que vendia roupas a domicílio, uma húngara dona de um restaurante, onde ele fazia as refeições e mesmo levava outras mulheres, sem pagar a conta, a caixeira dum grande armazém central (que lhe passava furtivamente litros de uísque), uma viúva 
com três filhos e alguma economia, a quem ele chamava de "mamita"; intermitentemente explorava uma velha cantora de rádio e a amante dum combativo deputado da oposição; tirava muito dinheiro das Mexicanitas, uma dupla de irmãs que cantava e dançava nos "inferninhos"; mensalmente dava um giro com uma professora solteirona magra como um cabo de vassoura, a quem pedia dinheiro para completar um curso de química, e finalmente noivava a sério com uma parteira que tinha a cara e as cicatrizes faciais do ex-pugilista Rocky Marciano, além de simples namoradas, entre estas, balconistas, manicuras e moças de espírito aberto. Um homem, sem ter a figura do Rodolfo Valentino, pode fazer muita coisa nesse terreno se se dispuser a trabalhar oito horas ou mais por dia com o afinco e a dedicação do Mon Gigolô. (REY, 1990, p. 59)

Há uma série de estratégias de que se vale Mon Gigolô para obter seu sustento junto as suas amantes. Primeiro, ele mandava-lhes flores, chocolates, dizia-se infeliz, por ter perdido a mulher amada, que morrera de uma doença horrível. Depois, convencia-as de que era filho único e tudo o que ganhava era para o sustento de uma mãe doente. Quando as conquistava, se fosse possível, mudava-se para o apartamento delas, alegando que não era ciumento e não se importava que tivessem amantes. No fragmento transcrito, pode se observar a relação maternal entre a viúva e Mon Gigolô pelo emprego do sintagma "mamita", desvelando o fato de ela ser a provedora, aquela que fornece sustento para o malandro. Do mesmo modo, outras mulheres fornecem bebidas (a caixeira), dinheiro para pagar por cursos que ele nunca frequentou (professora solteirona), alimentação (dona de restaurante), além de outras que ele enganava e extorquia. Não cabem dúvidas de que todas funcionam como a mulher-Deméter ou Ceres, que cuidam do malandro, exercitando a sua face materna e protetora, embora o aspecto sexual também esteja inserido em tais relações. Elas simbolicamente representam o papel tradicional da figura da mãe, orientando-se para o relacionamento e sua identidade e bem-estar. Além disso, elas "dependem de um relacionamento significativo. Expressam as necessidades das mulheres de adoção e vínculo. São sintonizadas aos outros e sensíveis" (RAPUCCI, 2011, p. 73).

No tratado terceiro do romance Lazarilho, quando Lázaro começa a servir o escudeiro, há uma verdadeira profusão de personagens femininas. As duas primeiras aparecem quando Lázaro vai ao rio buscar água, conforme seu amo ordenara: 
Arrumei a negra dura cama, peguei o jarro e fui ao rio, onde, numa horta, vi meu amo em grande conversa com duas mulheres embuçadas, ao que parecia das que naquele lugar não faziam falta. Mas, pelo contrário, muitas delas até têm por hábito ir, nas manhãzinhas de verão, refrescar-se e almoçar por aquelas frescas margens, sem nada levar, confiantes em que não há de faltar quem lhes ofereça o que comer, como costumam fazer os fidalgos do lugar.

Como ia dizendo, ele estava no meio delas, feito um Macias [Messias], dizendo-lhes mais galanteios do que todos os que Ovídio escreveu. Mas, ao perceberem que ele estava todo derretido, não tiveram vergonha de pedir que lhes desse almoço, em troca da costumeira recompensa. Ele, que tinha tanto frio no bolso como calor no estômago, sentiu um arrepio tão grande, que perdeu até a cor do rosto. Elas, que deviam ser muito sabidas, assim que perceberam a doença, deixaram-no no que ele era. (LAZARILHO..., 1992, p. 73).

Percebe-se que as duas mulheres que aparecem na cena transcrita são prostitutas, que pagam seus almoços prestando favores sexuais àqueles que lhes podem pagá-los. Os fragmentos "não tiveram vergonha" e "em troca da costumeira recompensa", relacionados a essas mulheres, revelam o ato de se prostituir dessas duas personagens, que querem tirar vantagens dos homens que cruzam o seu caminho. Elas são as únicas que se diferenciam das mulheres-Deméter que povoam o enredo do Lazarilho de Tormes, e se classificam em outra categoria, a das deusas alquímicas e, de acordo com as teorias de Jean Shinoda Bolen (1990), devem ser consideradas como mulheres-Afrodite.

Cleide Rapucci (2011, p. 74, grifo da autora), ao comentar esse tipo de mulher exposto por Jean Bolen, tece a seguinte observação: " $A$ mulher-Afrodite é regida pela deusa do amor, e está voltada principalmente para relacionamentos humanos, sexualidade, intriga, romance, beleza e inspiração nas artes." Conforme se verifica no excerto extraído do romance, as duas mulheres usam o sexo como moeda de troca, elas garantem a sobrevivência explorando as figuras masculinas. Nesse sentido, é importante destacar que Afrodite e as mulheres que se caracterizam como essa deusa, são "uma ameaça para a sociedade patriarcal, sendo frequentemente retratada[s] como sedutora[s], bruxa[s], mulher[es] fata[is]. Os homens são apresentados como vítimas" (RAPUCCI, 2011, p. 92), como é o caso do escudeiro, que é uma "presa" em potencial para 
as mulheres que Lázaro observa. No entanto, o papel de vítima não se confirma, uma vez que o escudeiro não tem nenhum dinheiro, é um ser miserável, que somente consegue enganá-las por um curto prazo, por meio de seu discurso, das belas palavras, cuja retórica vazia é percebida por elas, que o deixam só e vão explorar outras possibilidades.

Lázaro é obrigado a mendigar para si e para sustentar o escudeiro, que vive de aparências, fingindo viver com abundância, quando na verdade está tão ou mais faminto que o próprio pícaro. Numa das andanças de Lázaro, exercitando o ofício de pedinte de esmolas, no momento em que está regressando a sua casa, será auxiliado por uma mulher: "Retornei a casa e, ao passar por onde vendem tripas, pedi esmola a uma daquelas mulheres. Ela deu-me um pedaço de pata de vaca e algumas tripas cozidas" (LAZARILHO..., 1992, p. 75) e também serão as vizinhas que moram perto da casa de Lázaro e o escudeiro que o socorrerão, evitando que ele morra de fome:

Quem pudesse ver, aqui veria a abstinência da minha casa e a tristeza e o silêncio dos seus moradores, tanto que nos aconteceu ficarmos dois ou três dias sem comer nada, nem dizer uma palavra. Quem me salvou a vida foram umas mulherzinhas fiandeiras de algodão, que faziam barretes e viviam ao nosso lado, com que, além de vizinhar, mantive boas relações. Da miséria que ganhavam me davam alguma coisinha, com que eu ia levando a vida. (LAZARILHO..., 1992, p. 79).

Essas vizinhas ainda socorrem Lázaro em outras três situações difíceis que ele irá enfrentar. Na primeira delas, o escudeiro foge, porque não tem dinheiro para pagar o aluguel da casa e da cama, deixando o pícaro sozinho: "Chegara a noite, e ele não, tive medo de ficar sozinho, fui à casa das vizinhas, contei-lhes tudo e lá dormi” (LAZARILHO..., 1992, p. 85). Na segunda, serão as vizinhas que defenderão Lázaro dos credores do escudeiro, que o mandam prender, alegando que ele sabe onde está o seu amo:

As vizinhas, que estavam presentes, disseram:

- Senhores, este menino é inocente e faz poucos dias que está com esse escudeiro. Não sabe nada dele mais do que Vossas Mercês, até porque o pobrezinho vinha aqui a nossa casa e, por amor a Deus, dávamos-lhe de comer com o que podíamos e, à noite, ia dormir com ele.

Provada a minha inocência, largaram-me, devolvendo-me a liberdade. (LAZARILHO..., 1992, p. 87). 
Finalmente, a terceira vez que as vizinhas intercedem por Lázaro diz respeito ao novo amo para quem ele irá trabalhar: "Tive de procurar o meu quarto amo e foi este um frade das Mercês, que as mulherzinhas, de quem já falei, indicaram-me e a quem elas chamavam de parente" (LAZARILHO..., 1992, p. 89).

Nas três situações apontadas, as vizinhas atuam como mulheresDeméter, já que, efetivamente, salvam o pícaro da fome, de ser preso injustamente, e ajudam-no a conseguir um novo amo. Elas são protetoras, exercitam o seu instinto maternal, apiedam-se de Lázaro, agindo como se fossem "mães" dele, protegendo-o e alimentando-o. Contudo, como já comentamos, as mulheres são sempre rebaixadas nos relatos picarescos, fato que se comprova pelo vocábulo "mulherzinhas", que aparece em dois momentos do trecho citado, e também pelo fato de as vizinhas manterem uma relação ambígua com o religioso que se torna o quarto amo de Lázaro e a quem elas chamavam de "parente". Novamente, ainda que as vizinhas revelem-se generosas, solidárias com o pícaro, permanece a marca da degradação no uso do diminutivo, que faz com que o vocábulo equivalha a "prostitutas", "mulheres de condição vil", que se mantém graças a sua sexualidade, permutando-a por alimentos ou dinheiro, assim como as duas mulheres que solicitavam almoço ao escudeiro.

No conto do escritor paulista Marcos Rey, Mon Gigolô, além das conquistas que já comentamos, estabelece relações com três mulheres: Celina, por quem se apaixonará, a mulher do dono de uma firma comercial e uma mulher feia, mas que possuía dinheiro, Zuleika. As duas primeiras são mencionadas pelo narrador logo na abertura do conto:

O maior receio de Mon Gigolô era o de que alguém descobrisse que amava uma moça chamada Celina, a quem (verdade!) dava até dinheiro. [...] Por ela, inclusive, trabalhara durante dois meses a fio como uma espécie de relações públicas duma firma comercial, quando a esposa do patrão the ofereceu uma bela carteira de couro alemão e ele perdeu o emprego. (REY, 1990, p. 55).

O modo como Mon Gigolô perde o emprego faz supor que ele tenha mantido relações sexuais com a mulher de seu patrão ou que iria manter tais relações, fato que é indicado pelo presente caro, pela "bela carteira de couro alemão". O procedimento de aproximação empregado pelo malandro para conquistar Celina é o mesmo que ele já utilizara com as demais mulheres das quais ele se aproximara, com a intenção de explorá-las: 
Estava ele numa fase de sucesso, muito íntimo das Mexicanitas, quando conheceu a pequena e tênue Celina. Foi num trajeto de bonde. [...] (REY, 1990, p. 59).

Depois do judeu, Mon Gigolô apresentou a Celina um próspero corretor de imóveis, o Abreu. Este deixava algumas camisas no apartamento que ele usava. O Pestana, conhecido colunista de jornal, ajudou também, como pôde, o necessitado casal. Depois veio o italiano Gino, homem sério e compenetrado.

- Celina, quero apresentar-lhe o Romeu.

- Prazer, senhorita.

Romeu tinha um carro esporte, usava blusa de couro, e trabalhava num grande escritório do pai, a quem chamava de "papai”. Era a melhor apresentação que Mon Gigolô fizera a Celina, e com uma vantagem: o rapaz supunha que os dois fossem primos. Para afastar qualquer suspeita, Mon Gigolô deu a entender a Romeu que era homossexual. (REY, 1990, p. 64).

Diferentemente do que ocorre com o pícaro, que jamais se apaixona, Mon Gigolô passa a sentir ciúmes de Celina e o sentimento amoroso passa a dominá-lo, interferindo na sua atuação como gigolô: "Aquela semana tentou várias conquistas, todas fracassadas, inclusive com uma manicura que faturava bem. $\mathrm{O}$ amor atrapalhava-lhe os cálculos. Cometia erros, falhava o bote, saía tudo errado" (REY, 1990, p. 67). É precisamente nesse momento, quando acredita estar incapacitado de exercitar a sua capacidade de conquistar as mulheres, que se depara com uma mulher solitária, abastada, disposta a ser muito generosa:

Mon Gigolô pensava até em suicídio quando travou contato com uma senhora muito refinada, dona Zuleika. Dizendo-se ter sido diplomata, conseguiu conquistar-lhe $\mathrm{o}$ afeto. Ela morava num rico palacete com duas criadas e um motorista japonês. Mulher rica e generosa.

- Se você fosse pobre, gostaria de ser seu amante - dizialhe Mon Gigolô.

- Meu dinheiro impede?

- Impede, sim, porque sou pobre. Todo poeta é pobre. - E recitou, como seu, um poemeto de Guilherme de Almeida. (REY, 1990, p. 67). 
Zuleika irá pagar pelo afeto de Mon Gigolô, o qual lhe traz versos copiados de livros de poesia de Guilherme de Almeida (1890-1969) e Olegário Mariano (1889-1958). Apesar de o narrador afirmar que a paixão prejudicava a performance do malandro, ele ainda é capaz de conquistar mulheres mais velhas, carentes, que acabam por se transformar na sua fonte de renda, garantindo o seu sustento.

Se Mon Gigolô consegue dominar todas as mulheres que perpassam seu caminho, conquistando-as e, com extrema habilidade, transforma-as em objetos sexuais, que seduzem outros homens e lhe entregam o que ganham, Celina parece ser a única que conseguirá libertar-se de seu jugo, uma vez que um de seus clientes, Romeu, apaixona-se por ela e os dois pretendem casar-se. No entanto, ao invés de livrar-se do malandro, Celina revela-lhe que quer manter o triângulo amoroso, e o dinheiro de Romeu será usado para garantir a sobrevivência de Mon Gigolô:

Numa dessas noites, Romeu deu a notícia:

- Sabe que eu e ela vamos casar? Sabia, primo?

Era verdade, Celina confirmava. Os papéis estavam prontos: haviam corrido na surdina.

- E sabe quem será o padrinho?

- Aceito - respondeu Mon Gigolô, sorrindo com hipocrisia. Celina segurou-lhe a mão sobre a mesa, pela primeira vez sentindo que ela o amava.

- Visitarei você - disse ela. - Afinal, somos primos.

Desta vez ele sorriu de verdade: a coisa ia continuar, mais pecaminosa com o casamento. $\mathrm{O}$ enganado seria Romeu. Celina, amante do padrinho, do falso primo. Voltaria a ser o verdadeiro Mon Gigolô.

Quem sabe, até através dela, conseguisse dinheiro do marido otário?

- Uma vez por semana irei ver você - ela confirmava.

[...]

- Boa noite, padrinho! - exclamou Celina.

Mon Gigolô piscou marotamente um olho [...]. (REY, 1990, p. 70).

Assim, as três figuras femininas que surgem no final do relato de Mon Gigolô - a esposa do dono da firma comercial, Zuleika e Celina - conformam traços da deusa Deméter, porque elas funcionam como provedoras para o malandro e as duas últimas fornecem-lhe o sustento, garantem a sua sobrevivência, pois entre a amante rica, idosa e feia e a razão 
do seu afeto, Celina, que corresponde ao seu amor, Mon Gigolô triunfa, é o "queridinho" das mulheres, a figura que se disfarça de "ser desamparado", infeliz, para manter e cultivar a afeição dessas deusas-mulheres, que o adotam como parceiro sexual, infantilizando-o e, por seu turno, tornando-o dependente de sua generosidade e de seu poder econômico.

A propósito de imagens sobre a mulher brasileira, o sociólogo Roberto da Matta (1990, p. 116) afirma que ela é vista sob duas polaridades antagônicas:

[...] a mulher tem - no Brasil e no mundo mediterrâneo uma posição ambígua, com duas figuras paradigmáticas lhe servindo de guia. A da Virgem-Maria, isto é, da mulher que tem sua sexualidade controlada pelo homem a serviço da sociedade e de ser, como lhe aponta o exemplo supremo, mãe permanecendo Virgem. E a da mulher como puta. A mulher que não é controlada pelos homens. Ao contrário, ela é controladora e centro de uma rede de homens de todos os tipos, pois quem é a puta senão aquela que põe todos os homens em relação? Como Virgem-Mãe, a mulher não tem senso de comparação nem de medida, seu poder sendo dado pela virtude. Como puta, ela reprime e susta seu poder reprodutivo (pois a mãe-puta é uma ofensa e uma contradição), tornando-se, por outro lado, um centro de poder comparativo e controlador da sexualidade masculina. Assim, como Virgem-Mãe a mulher abençoa e honra seu lar. E como puta ela confere masculinidade aos homens. Num caso, a mulher coloca os poderes reprodutivos acima dos favores (e prazeres) sexuais, (é a Virgem-Maria); noutro, ela coloca sua sexualidade acima da reprodução (é a prostituta).

As mulheres retratadas nas obras em análise neste artigo apresentam essa ambiguidade assinalada por Da Matta, uma vez que são capazes de atitudes altruístas, realizam sacrifícios pelos homens com quem se relacionam e, por outro lado, não deixam de estar ligadas ao universo da rua, do desejo, escancarando a sua sexualidade.

A dualidade comentada por Da Matta aponta para os estereótipos que circundam as figuras femininas não só na sociedade brasileira, mas também no território da literatura. A esse respeito, Lúcia Osana Zolin (2009, p. 226) assevera que 
[...] é recorrente o fato de as obras literárias representarem a mulher a partir de repetições de estereótipos culturais, como, por exemplo, o da mulher sedutora, perigosa e imoral, o da mulher como megera, o da mulher indefesa e incapaz e, entre outros, o da mulher como anjo capaz de se sacrificar pelos que a cercam. Sendo que à representação da mulher como incapaz e impotente subjaz uma conotação positiva; a independência feminina vislumbrada na megera e na adúltera remete à rejeição e à antipatia.

$\mathrm{Na}$ ficção, é possível encontrar personagens femininas que se configuram como seres diabólicos, ligados ao pecado, ao prazer, vistas negativamente, ou como seres angelicais, abnegados, encarados positivamente:

Na literatura brasileira, muitas são as obras que retratam a mulher segundo esses estereótipos. Em Luciola, de José de Alencar, Lúcia transita da menina inocente à prostituta imoral, para posteriormente regenerar-se, encarnando a mulher-anjo, capaz de sacrificar-se pelo bem dos que a cercam. Em Dom Casmurro, de Machado de Assis, Capitu é, na visão do marido Bento, uma sedutora imoral e dissimulada, capaz de traí-lo com seu melhor amigo. Também na literatura portuguesa são abundantes as figuras estereotipadas. Em Amor de perdição, Teresa encarna a mocinha indefesa afastada de seu grande amor, em razão das rivalidades reinantes entre as duas famílias. Em $O$ primo Basílio, Eça de Queiroz põe em cena a megera chantagista, na pele de Juliana, e a adúltera imoral na pele de Luísa. (ZOLIN, 2009, p. 226-227).

Nessas representações do feminino, pode-se perceber que as mulheres refletem imagens padrões da sociedade brasileira patriarcal e acabam servindo ao propósito da dominação social e cultural masculina, conforme enfatiza a estudiosa Zolin (2009, p. 227).

Nesse sentido, as mulheres do conto "Mon Gigolô" e do romance de autoria desconhecida que inaugura o gênero picaresco, apesar de, em muitos momentos, confirmarem os estereótipos comentados, elas também assinalam uma evolução, uma vez que amalgamam em seu comportamento as duas polaridades mencionadas e vão da figura sedutora, que goza de uma certa liberdade, até a imagem da mãe, que se sacrifica para prover o sustento de seus homens. 
Semelhantemente ao conto "Mon Gigolô", as aventuras de Lázaro de Tormes encerram-se com a formação de um triângulo amoroso, no qual a mulher transforma-se em objeto de troca e assegura o sustento do pícaro. No sétimo tratado, Lázaro encontra-se numa posição estável, tem o cargo de pregoeiro (vendedor) de vinhos e conhece o seu último amo, o arcipreste de São Salvador, novamente, a figura de um religioso (lembremos que cinco dos amos de Lázaro pertencem à igreja). Tais religiosos são bastante criticados no romance e o arcipreste não é exceção, tendo em vista a forma premeditada com a qual age em relação ao pícaro e a sua criada/amante:

Por essa época, vendo a minha habilidade e o meu bom viver, tendo notícia de minha pessoa, o senhor arcipreste de São Salvador, meu senhor, servidor e amigo de Vossa Mercê, porque eu lhe apregoava seus vinhos, procurou casar-me com uma criada sua. Como vi que de tal pessoa não podia receber senão bem e favor, concordei em fazê-lo. Assim, casei-me com ela e até hoje não estou arrependido, porque, além de ser ela boa moça e diligente serviçal, recebo do meu senhor, o arcipreste, todo o favor e auxílio. E sempre no ano lhe dá, em várias vezes, perto de uma carga de trigo; pela Páscoa, sua carne e, por ocasião da oferenda dos pães, as calças velhas que deixa de usar. E fez-nos alugar uma casinha perto da sua; aos domingos e em quase todos os dias de festa comíamos em sua casa.

Mas as más línguas, que nunca faltaram nem faltarão, não nos deixam viver com o disse-não-disse de que vêem a minha mulher ir fazer a cama e cozinhar para ele comer. [...] (LAZARILHO..., 1992, p. 103).

Nos momentos finais do romance, o arcipreste conversa com Lázaro sobre as murmurações a respeito da honestidade de sua mulher, garantindo que nada é verdadeiro e que ele deveria ignorar tais comentários que visavam desaboná-la:

- Lázaro de Tormes, quem se preocupa com o que dizem as más línguas nunca progredirá; digo isso porque não me admiraria algum falatório pelo fato de sua mulher ser vista entrando e saindo da minha casa. Ela entra honrando a você e a si mesma. Isso eu lhe garanto. Portanto, não dê importância ao que possam dizer, mas apenas ao que lhe interessa, quer dizer, ao seu proveito. 
- Senhor - disse-lhe -, resolvi aproximar-me dos bons. É verdade que alguns dos meus amigos me falaram alguma coisa, e por mais de três vezes me asseguraram que, antes de casar-se comigo, ela tinha parido três vezes, [...]

Então minha mulher jurou por sua vida, a ponto de eu pensar que a casa cairia em cima de nós. Depois começou a chorar e a lançar maldições sobre quem a tinha casado comigo, de tal modo que eu preferiria estar morto do que ter dito aquelas palavras. Mas eu de um lado e o meu amo do outro, tanto falamos e concedemos, que ela parou de chorar, com a promessa de que nunca mais na minha vida eu mencionaria nada daquilo, e que eu gostava e achava bem que ela ali entrasse e saísse, de noite ou de dia, pois estava convencido de sua bondade. Assim, ficamos satisfeitos todos os três. (LAZARILHO..., 1992, p. 105).

É a figura feminina quem irá possibilitar a sobrevivência de Lázaro, que se conforma em viver uma relação triangular formada por ele, sua mulher e o arcipreste. Ao continuar como amante do religioso, mesmo depois de casada, ela garante o alimento, as roupas e o abrigo para si e para o marido, confirmando que ela também tangencia a figura da mulher-Deméter, que protege, ampara e concede a fartura para o elemento masculino, apesar da relação degradante que a objetifica e a torna moeda de troca no universo dominado pela visão patriarcal, na qual o homem é a figura predominante e opressora da mulher.

Em síntese, o sentimento de maternidade ou de mãe que permeia as atitudes das mulheres do conto "Mon Gigolô" e do romance Lazarilho de Tormes, possibilitam que possamos aproximá-las da deusa grega Deméter. Ao se referir a essa figura mitológica, a estudiosa Cleide Rapucci (2011, p. 85) tece o seguinte comentário:

Deméter, deusa do cereal, presidia abundantes colheitas. Era venerada como uma deusa mãe, [...]. O arquétipo da mãe era representado no monte Olimpo por Deméter, cujos papéis mais importantes foram o de mãe, de fornecedora de alimentação e de alimento espiritual. $\mathrm{O}$ arquétipo da mãe motiva as mulheres a nutrirem os outros, a serem generosas no dar, e a encontrarem satisfação como alguém que zela e provê a subsistência. [...]

[...] a mulher-Deméter é aquela que tem uma atitude de mãe: uma maneira instintiva de cuidar de tudo o que é 
pueril, pequeno, carente e sem defesa. Deméter identificase plenamente com todas as atividades da maternidade, vivendo quase inteiramente para os filhos. [...] Deméter é regida pelo amor. [...] ela vive para o outro, ela se dá para o outro e se perde no outro. [...] para Deméter [o ser amado] é a criança.

Tanto as representações femininas que encontramos no relato do malandro Mon Gigolô, quanto aquelas que localizamos em Lazarilho de Tormes, são figuras que exercitam o seu lado materno, que se mescla também com a esfera sexual, e ambos se complementam, pois essas mulheres terminam por transformar os seres masculinos em elementos dependentes, fragilizados, inertes, que precisam de sua atenção, proteção, carinho e supervisão. São "crianças crescidas" que, ao mesmo tempo em que acreditam que as manipulam, são manipulados e transformados em eternos dependentes de seu afeto e de sua capacidade de gerenciar e administrar o seu sentimento, mantendo relações triangulares em equilíbrio, juntando amantes pobres e ricos debaixo do mesmo teto e garantindo a felicidade de todos, numa atitude que recupera as ações da mulher-Deméter, que se ocupa daqueles que são indefesos, carentes, ou seja, personagens masculinas, incapazes de sobreviver por si sós, sem a sua proteção, o seu zelo e a garantia da sua subsistência que ela lhes oferece.

É válido salientar que as representações femininas estudadas neste artigo não ficam reduzidas apenas à atuação do papel maternal associado à deusa Deméter, mas extrapolam essa dimensão ao conjugar em suas ações atitudes maternais e sexuais, de vítimas e algozes da figura masculina, subvertendo o maniqueísmo que se observa em diversas obras canônicas. Pode-se afirmar que tais mulheres, em consonância com a contemporaneidade e com as mudanças verificadas na construção de personagens femininas, deixaram de lado a passividade e se lançaram à aventura de se transformarem em sujeitos ativos, capazes de conjugar aspectos positivos e negativos, adquirindo uma dimensão plural e multifacetada no universo da ficção, problematizando até mesmo a maneira como eram representadas no passado.

\section{Referências}

BARBOSA, L. M. F.; RODRIGUES, M. S. P. Da tradição picaresca ao malandro malazartiano: o caso brasileiro Murilo Mendes. In:

A trama poética de Murilo Mendes. Rio de Janeiro: Lacerda Editores, 2000. p. 51-66. 
BOLEN, J. S. As deusas e a mulher: nova psicologia das mulheres. Tradução de Maria Lydia Remédio. São Paulo: Paulinas, 1990.

CARMO, J. C. M. do. Madame Pommery: a primeira malandra na prosa ficcional brasileira. 2003. 123 f. Dissertação (Mestrado em Literatura) Universidade Federal de Santa Catarina, Florianópolis, 2003.

COELHO, M. J. B. A representação do feminino na picaresca espanhola: el ajuar de las pícaras-putas. [S.1.: s.n.], 2009. p. 1593-1601. Disponível em: $<\mathrm{http}: / / 150.164 .100 .248 /$ espanhol/Anais/anais paginas \%2015022009/A\%20representa\%E7\%E3o.pdf>. Acesso em: 26 dez. 2014.

COELHO, M. J. B. Meu tio Atahualpa de Paulo de Carvalho Neto: o enigma mulher no universo feminino do romance malandro. 2006. 137 f. Dissertação (Mestrado em Literatura e Vida Social) - Faculdade de Ciências e Letras de Assis, Universidade Estadual Paulista "Júlio de Mesquita Filho", Assis, 2006.

COMMELIN, P. Mitologia grega e romana. Tradução de Thomaz Lopes. Rio de Janeiro: Tecnoprint, [s.d.].

DA MATTA, R. Carnavais, malandros e heróis: para uma sociologia do dilema brasileiro. 5. ed. Rio de Janeiro: Editora Guanabara, 1990.

ESTILL, D. A. Formação malandra: Bildungsroman e picaresca em Memórias sentimentais de João Miramar e Amar, verbo intransitivo. 1996. 126 f. Dissertação (Mestrado em Teoria Literária e Literatura Comparada) - Faculdade de Filosofia, Letras e Ciências Humanas, Universidade de São Paulo, São Paulo, 1996.

GONZÁLEZ, M. M. A saga do anti-herói: estudo sobre o romance picaresco espanhol e algumas de suas correspondências na literatura brasileira. São Paulo: Nova Alexandria, 1994.

GONZÁLEZ, M. M. Lazarillo de Tormes. In:__. Leituras da literatura espanhola (da Idade Média ao Século XVII). São Paulo: Letraviva, Fapesp, 2010. p. 302-336.

LAZARILHO de Tormes. Tradução de Pedro Câncio da Silva. São Paulo: Página Aberta; Brasília: Cosejería de Educación de la Embajada de España, 1992. (Collección Orellana, 4).

MILTON, H. C. A picaresca espanhola e Macunaíma de Mário de Andrade. 1986. 106 f. Dissertação (Mestrado em Letras Modernas) - 
Faculdade de Filosofia, Letras e Ciências Humanas, Universidade de São Paulo, São Paulo, 1986.

RAPUCCI, C. A. Mulher e deusa: a construção do feminino em Fireworks de Angela Carter. Maringá: Eduem, 2011.

REY, M. Mon Gigolô. In: . O enterro da cafetina. São Paulo: Círculo do Livro, 1990. p. 53-70.

ZOLIN, L. O. Crítica feminista. In: BONNICI, T.; ZOLIN, L. O. Teoria literária: abordagens históricas e tendências contemporâneas. 3. ed. rev. e aum. Maringá: Eduem, 2009. p. 217-242. 
